\title{
FATHOM
}

\section{The Use of Weapons for the Production of the Uncanny in Hardy and Conrad}

L'utilisation des armes et l'inquiétante étrangeté chez Hardy et Conrad

\section{Andrew Hewitt}

\section{(2) OpenEdition \\ 1 Journals}

\section{Electronic version}

URL: http://journals.openedition.org/fathom/1640

DOI: 10.4000/fathom.1640

ISSN: 2270-6798

\section{Publisher}

Association française sur les études sur Thomas Hardy

\section{Electronic reference}

Andrew Hewitt, «The Use of Weapons for the Production of the Uncanny in Hardy and Conrad », FATHOM [Online], 6 | 2019, Online since 01 October 2019, connection on 16 October 2019. URL : http:// journals.openedition.org/fathom/1640; DOI : 10.4000/fathom.1640 


\title{
The Use of Weapons for the Production of the Uncanny in Hardy and Conrad
}

\author{
L'utilisation des armes et l'inquiétante étrangeté chez Hardy et Conrad
}

\author{
Andrew Hewitt
}

1 This paper suggests three ways in which Hardy's use of a particular subcategory of objects, namely weapons, contributes to the production of the uncanny in his texts. First, weapons may appear out of nowhere; second, anything can be a weapon; and third, weapons, like many objects in Hardy, seem to have a degree of agency of their own. I am particularly interested in the carving-knife used as a murder weapon in Tess of the d'Urbervilles, not least because it appears again in much the same context and to much the same end in Joseph Conrad's The Secret Agent. This carving-knife is one of three objects singled out for dispraise by an early "genteel" reader of Tess, as Hardy recalls in his Preface to the Fifth Edition: according to this critic, "such vulgar articles as the Devil's pitchfork, a lodging-house carving-knife, and a shame-bought parasol" had no place "in a respectable story" (Hardy 2008b, 5). It is, however, presumably not the "article" itself that is being censured, but the use to which it is put. In fact we do not even see the carving-knife until after it has been weaponised, so to speak: when Mrs Brooks, the landlady of the fashionable boarding-house where Tess and Alec have been staying, enters their rooms just after the murder, everything seems to be in order, except that "the carving knife [is] missing" from the breakfast table (405). Notable by its absence, the carving-knife has in this sense come out of nowhere, to be used as a weapon by Tess - although even this is not completely clear, for although she confesses to the crime, nobody saw her pick up the knife, nobody saw her stab Alec. The question of agency is thus left open: did the knife itself act upon Alec in some way? I will begin with some general observations about weapons in Hardy before turning to a range of specific examples to support my claims that weapons may appear without warning, out of nowhere; that anything may be a weapon; and that weapons have agency - factors that together contribute to the sense of the uncanny in Hardy. I will then return to the 
carving-knife to suggest some grounds of comparison between Tess of the d'Urbervilles and The Secret Agent.

Hardy's work incorporates hundreds of references to arrows, cannons and artillery, guns and pistols, swords and pikes, as well as to a range of improvised weapons of a sometimes bizarre and unsettling nature. Some of these weapons are "real", that is, imagined as actually present in the story. In Far from the Madding Crowd, Sergeant Troy famously performs the sword-exercise for Bathsheba, not with a walking-stick but - as Bathsheba insists - with a "real sword" (Hardy 2002, 180); and Troy is later killed by a real shotgun. In The Return of the Native, Diggory Venn takes potshots at Damon Wildeve as part of the escalating campaign of "menace" intended to keep Wildeve from rekindling his affair with Eustacia Vye (Hardy 1990, 273). In A Laodicean, Will Dare draws a pistol while searching the bedroom he shares with the architect Havill, and again when he confronts Abner Power, the "political regenerator" (Hardy 1997, 328). But weapons also feature in simile and metaphor. "My thoughts go through me like swords", says Clym Yeobright (Hardy 1990, 312), and Michael Henchard is embarrassed when Elizabeth-Jane, instead of writing in "ladies-hand", produces "a line of chain-shot and sand-bags", that is, blots and loops rather than neatly-formed upright letters (Hardy 2008a, 122). There is one example of a bomb in Hardy, which interestingly, for a comparison with Conrad's The Secret Agent, goes off accidentally (Hardy 1997, 327). References to weapons are also used to create patterns, as in Far from the Madding Crowd when Gabriel's proposal to Bathsheba is at first coolly received ("Bathsheba did not look quite so alarmed as if a cannon had been discharged by her ear, which was what Oak had expected. "Marrying me - I didn't know it was that you meant," she said quietly. "Such a thing as that is too absurd - too soon - to think of by far", Hardy 2002, 382), but eventually accepted and acted upon: "Just as Bathsheba was pouring out a cup of tea their ears were greeted by the firing of a cannon followed by what seemed like a tremendous blowing of trumpets in the front of the house. 'There!' said Oak laughing, 'I knew those fellows were up to something, by the look on their faces"' (388). Oak's proposal is not so startling as a cannon going off in Bathsheba's ear would be; in the next chapter, a cannon actually going off in their ears to celebrate their marriage is not so startling either: "I knew those fellows were up to something". The back-to-front symmetry of the two clauses "a cannon had been discharged by her ear [...]" / "their ears were greeted by the firing of a cannon [...]" is surely deliberate, a way of notating the reversal of Bathsheba's position in the structure of the sentences that bookend it.

More poignant is the parallelism of the straight arrows in Jude the Obscure. The simile "straight as an arrow" to describe a supine body occurs twice in the novel, first in the context of Jude's seduction by Arabella ("She lay supine, and straight as an arrow, on the sloping sod of this hill-top, gazing up into the blue miles of sky, and still retaining her warm hold of Jude's hand. He reclined on his elbow near her", Hardy 2008c, 47), and then again at the end of the novel, when Jude himself is stretched out on his deathbed under the same cloudless sky:

By ten o'clock that night Jude was lying on the bedstead at his lodging covered with a sheet, and straight as an arrow. Through the partly opened window the joyous throb of a waltz entered from the ball-room at Cardinal.

Two days later, when the sky was equally cloudless, and the air equally still, two persons stood beside Jude's open coffin in the same little bedroom (396)".

While Arabella is always quite undeviating in her purpose, Jude is an arrow that has missed its mark - though in recalling, via his body language ("straight as an arrow"), 
the moment his life first veered off course, the narrative suggests that his superficially wandering, aimless life may have followed a well-defined trajectory after all.

For a novel set during the Napoleonic Wars, The Trumpet-Major is more invested in the gradual domestication of lethal weapons, their subsidence into implements of peacetime life, than it is in describing their deployment in military exercises, let alone actual battles:

[...] The religion of the country had, in fact, changed from love of God to hatred of Napoleon Buonaparte; and, as if to remind the devout of this alteration, the pikes for the pikemen (all those accepted men who were not otherwise armed) were kept in the church of each parish. There against the wall they always stood, a whole sheaf of them, formed of new ash stems, with a spike driven in at one end, the stick being preserved from splitting by a ferule. And there they remained, year after year, in the corner of the aisle, till they were removed and placed under the gallery stairs, and thence ultimately to the belfry, where they grew black, rusty, and wormeaten, and were gradually stolen and carried off by sextons, parish clerks, whitewashers, window-menders, and other church-servants for use at home as rake-stems, benefit-club staves and pick-handles, in which degraded situations they may still occasionally be found. (Hardy 1991, 196)

The tendency of weapons to blend in with the tools of peaceable rural life is explained in a passage from Far from the Madding Crowd:

[...] she found Gabriel Oak at the bottom of her garden, grinding his shears for the sheep shearing. All the surrounding cottages were more or less scenes of the same operation; the scurr of whetting spread into the sky from all parts of the village as from an armoury previous to a campaign. Peace and war kiss each other at their hours of preparation, sickles, scythes, shears, and pruning-hooks mingling with swords, bayonets and lances in their common necessity for point and edge. (Hardy 2002, 131)

7 This verges on the commonplace, but there is an underlying message, I believe, about the vanity of war, which comes across most clearly in the poem "Channel-Firing", where the heavy artillery blazes away at non-combatants - the dead, who only want to be left to their slumbers, and the church mice who only want to be left to their crumbs:

That night your great guns, unawares,

Shook all our coffins as we lay,

And broke the chancel window-squares,

We thought it was the Judgment-day

And sat upright. While drearisome

Arose the howl of wakened hounds:

The mouse let fall the altar-crumb,

The worms drew back into the mounds,

The glebe cow drooled. Till God called, "No;

It's gunnery practice out at sea

Just as before you went below;

The world is as it used to be [...]"

Again the guns disturbed the hour,

Roaring their readiness to avenge,

As far inland as Stourton Tower,

And Camelot, and starlit Stonehenge. (Hardy 1976, 305-306)

8 We may think also of "In Time of 'The Breaking of Nations"', which although it does not mention any weapons juxtaposes the timeless quality of the love between "maid" and "wight" to the annals of war and the passing of dynasties (543). 
9 The insinuation into private, domestic, "everyday" life by weapons designed for impersonal combat epitomised in "Channel-Firing" is met by a movement in the opposite direction which sees the conversion of everyday objects such as knitting needles, parasols, pokers, the carving-knife in Tess or the box-cord in Jude, into dangerous weapons. Susan stabs Eustacia in church with a "long stocking-needle [...] so as to draw her blood, and put an end to the bewitching of Susan's children that has been carried on so long" (Hardy 1990, 179). A parasol is weaponised by the people of Mixen Lane in the scene of the skimmington-ride in The Mayor of Casterbridge. Watching from her window, Lucetta sees the effigy of herself, yoked to her former lover Henchard, being paraded through the streets:

Lucetta's eyes were straight upon the spectacle of the uncanny revel, now dancing rapidly. The numerous lights round the two effigies threw them up into lurid distinctness... "She's me - she's me - even to the parasol - my green parasol!" cried Lucetta with a wild laugh as she stepped in. She stood motionless for one second then fell heavily to the floor. (Hardy 2008a, 259-260)

10 While Elizabeth-Jane carries a "sun-shade" for her complexion, Lucetta has the more elevated "parasol"; but now it seems as if the parasol has betrayed her, gone over to the other side. No mere prop for the representation of a generic fashionable lady, but the object that identifies Lucetta to herself beyond any doubt, and thus, by a massive discharge of shame, brings about her seizure and death, the parasol is without a doubt a dangerous weapon. In the same novel, Henchard brandishes a poker at the choristers to make them sing a psalm that will bring down a curse on Donald Farfrae, and then bends the poker in two to show how he would like to deal with Farfrae himself (Hardy 2008a, 215-216). In Tess, Dairyman Crick uses breakfast cutlery to prefigure Tess's fate:

11 "I don't - know about ghosts," she was saying. "But I do know that our souls can be made to go outside our bodies when we are alive."

The dairyman turned to her with his mouth full, his eyes charged with serious inquiry, and his great knife and fork (breakfasts were breakfasts here) planted erect on the table, like the beginning of a gallows. (Hardy 2008b, 135)

Tess will complete her passage to the gallows by taking up another "great knife" from another table laid for breakfast: "The room was empty; the breakfast - a substantial repast of coffee, eggs, and a cold ham - lay spread upon the table untouched, as when she had taken it up, excepting that the carving-knife was missing" (405). While the "great guns" blast away at cows and mice, the hearth and the breakfast-table are miniarsenals, bristling with deadly weapons. That domestic objects in particular - familiar household items, ordinary appurtenances of home - can be so swiftly and unexpectedly transformed into the means of threat and attack might suggest a link with Freud, whose essay "The Uncanny" analyses the unheimlich, the eerie sensation that accompanies an eruption of the strange into the familiar. The literal meaning of the word is "unhomely", as in "unfamiliar", "untamed", but it is typically translated into English as "uncanny", which however loses the sense of "home" as the safe place which the unheimlich destabilises. ${ }^{1}$ In an anecdote included in Martin Ray's anthology Thomas Hardy Remembered, Henry Woodd Nevinson recalls emerging from a tea-room in April 1906 with Hardy, who was shocked by the broadsheet headline: "Family Murdered with a Pen-Knife": "He couldn't get over that. The vision of the pen-knife seemed to fascinate him" (Ray 135). By far the most macabre use of a domestic object as a murder weapon is in the poem "Her Second Husband Hears the Story", where a wife matter-offactly confesses to her second husband that she suffocated the first by sewing him up so 
tightly in his bed-clothes when he came home drunk that he could not breathe. "Here it came about", she says, presumably indicating the bed, but it is an interesting turn of phrase, as if to suggest that the event somehow just happened, without human intervention (Hardy 1976, 860). ${ }^{2}$

Chekhov's advice to playwrights was that if there is a pistol hanging on the wall in the first act, by the third act it must go off. Hardy's practice seems to be the exact opposite: often, guns and knives and other weapons are introduced only after they have been used. Consider the murder of Sergeant Troy in Far from the Madding Crowd: the first time we read of Farmer Boldwood's gun is in fact after it has gone off. If it was hanging on the wall in the first act, it was invisible. Like Troy, who appears out of nowhere at Boldwood's Christmas party, which is also meant to be a celebration of Boldwood's engagement with Bathsheba, the gun is just suddenly there, primed and loaded. Troy lays hands on Bathsheba to claim her:

[...] she writhed, and gave a quick, low scream.

The scream had been heard but a few seconds when it was followed by a sudden deafening report that echoed through the room and stupefied them all. The oak partition shook with the concussion, and the place was filled with grey smoke.

In bewilderment they turned their eyes to Boldwood. At his back [...] was a gunrack, as is usual in farmhouses, constructed to hold two or three guns. When Bathsheba had cried out in her husband's grasp, Boldwood's face of gnashing despair had changed. The veins had swollen and a frenzied look had gleamed in his eye. He had turned quickly, taken one of the guns, cocked it, and at once discharged it at Troy.

Troy fell. The distance apart of the two men was so small that the charge of shot did not spread in the least, but passed like a bullet into his body. (Hardy 2002, 367)

Brooks, the landlady of The Herons, peers through the keyhole of the suite of rooms
occupied by that fashionable couple, Tess and Alec, she sees the breakfast-table already laid. There is no mention of any carving-knife; why should there be? A carving-knife is "usual" on a breakfast-table. Only later, when the landlady enters the room, having become alarmed by the sight of blood pooling on her ceiling, does she notice the carving-knife, by its absence:

The room was empty; the breakfast - a substantial repast of coffee, eggs, and a cold ham - lay spread upon the table untouched, as when she had taken it up, excepting that the carving knife was missing. She asked the man to go through the foldingdoors into the adjoining bedchamber.

He opened the doors, entered a step or two, and came back almost instantly, with a rigid face. "My good God, the gentleman in bed is dead! I think he has been hurt with a knife [...]" (Hardy 2008b, 405)

The weapon, in other words, only makes its appearance after it has been used. Then follows the explanation - "a lot of blood had run down upon the floor [...]. The wound was small, but the point of the blade had touched the heart of the victim". Hardy could

FATHOM, 6 | 2019 
have left the carving-knife out on the table, as it were, for us to see through the landlady's eyes; he could have written: "The breakfast table was already spread with plates, glasses, and all the implements necessary for the meal, including a carvingknife...". That would have been more compliant with Chekhov's law. Strictly speaking, what Chekhov says is that there should be no gratuitous exhibition of weapons: if there is a pistol in the first act, it must go off. He does not stipulate the reverse - that any weapon used in the course of the action must have been introduced at an earlier point. So we cannot say Hardy is guilty of breaking the rule. But I think the assumption underlying Chekhov's law is that events proceed in a linear fashion: you cannot go back on yourself and conjure up a weapon that you forgot to mention first time around, just because you suddenly need it for the purposes of the plot. It is out of respect for this assumption that the narrator of Stendhal's The Charterhouse of Parma feels obliged to confess his oversight when he describes two characters boating on a lake near the Swiss-Italian border, without having first explained how they come to be in that setting: "We have forgotten to mention, in its proper place, that the Duchessa had taken a house at Belgirate, a charming village and one that fulfils all the promise of its name (i.e. the view of a beautiful bend in the lake)" (Stendhal 398). In this case, the failure to mention something in its proper place is easily forgiven. It is taking a much greater risk to withhold mention of an object as important as a gun or a knife that features in the climax of the story, until after it has been used.

This is not to suggest that the use of weapons is completely unpredictable in Hardy, simply because he does not introduce guns or knives to the narrative in a timely way. There is plenty of foreshadowing in the novels. With regard to the violent fate of certain human characters, I would like to highlight a particular pattern that arises, I believe, out of Hardy's belief in the kinship of all animals. Recall Hardy's comments about the significance, for him, of the discovery of natural selection as the mechanism of evolution and the need for the "centre of altruism" to "shift" away from humankind exclusively to embrace all living creatures: "the most far-reaching consequence of the establishment of the common origin of all species is ethical; [...] it logically involve[s] a re-adjustment of altruistic morals by enlarging as a necessity of rightness the application of what has been called 'The Golden Rule' beyond the area of mere mankind to that of the whole animal kingdom" (Hardy 1989, 376-377). Darwinism demands the extension of "do unto others" to dogs, horses, sheep, blackbirds, snails, butterflies, and so on. Now, the novels do not spare such creatures any more than they spare the humans. Indeed, the first character to be killed by a gun in Far from the Madding Crowd is Gabriel's over-enthusiastic sheepdog, "taken and tragically shot" for his part in causing the fatal stampede of Gabriel's sheep (Hardy 2002, 42). Troy is several times compared to a "dog", for example when he says of himself to Bathsheba, "I am thankful for beauty, even when 'tis thrown to me like a bone to a dog" (163), or when Gabriel describes him as, "That man of a family that has come to the dogs" (189), or when a rustic predicts of Troy that, "He'll drag [Bathsheba] to the dogs" (358). To be sure, Boldwood also compares himself to a dog who has had his day. Nevertheless I believe Troy's fate to be an instance of a curious economy in Hardy's works, based in a sense on the Golden Rule, which dictates that when an animal is killed, a human character will later die by the same means. We see this much more clearly in Tess, where the fate of the horse, Prince, accidentally stabbed by the rushing mail-cart, foreshadows the murder of Alec, that prince of darkness, and his terrible loss of blood on the bed in the lodging-house. Alec does not just bleed, his blood pours out, flooding the bedclothes, the mattress, the 
carpet, and the floor, at a speed and in a quantity sufficient to seep right through and stain the ceiling of the room below, and all this from a "small" wound that is still stoppered by the carving-knife plunged into his chest. From a realist perspective, this is not credible; in my view, the best way to account for the sheer profusion of blood is by reference to the earlier scene of the horse's death:

A sudden jerk shook her in her seat, and Tess awoke from the sleep into which she, too, had fallen. [...]

[T] he waggon had stopped. A hollow groan, unlike anything she had ever heard in her life, came from the front. [...]

Something terrible had happened. The harness was entangled with an object which blocked the way.

In consternation Tess jumped down, and discovered the dreadful truth. The groan had proceeded from her father's poor horse Prince. The morning mail-cart, with its two noiseless wheels, speeding along these lanes like an arrow, as it always did, had driven into her slow and unlighted equipage. The pointed shaft of the cart had entered the breast of the unhappy Prince like a sword; and from the wound his life's blood was spouting in a stream, and falling with a hiss into the road. [...]

The huge pool of blood in front of her was already assuming the iridescence of coagulation [...] Prince lay alongside still and stark; his eyes half open, the hole in his chest looking scarcely large enough to have let out all that had animated him. (Hardy 2008b, 38-39)

Once again, the weapon is only introduced after it has done its work; first Tess's waggon comes to an abrupt halt and we hear the terrible groan, then we learn of the collision with the mail-cart and the way its shaft "had entered" the breast of the horse. Note the size of the wound, which like Alec's is perceived as small, though it has "let out" everything. In leaving her native sphere, Tess has entered a kind of parallel "economy of blood" or blood-nexus in which relations among people are governed by blood. The profligate spilling of Prince's blood leaves Tess in the position of a labourer who must put herself out not for wages, but in the hope that Alec will link "his blood" to hers. In this parallel economy, only when a like quantity of Alec's blood is poured forth will the debt owed to Prince ever be paid; that is why Alec's death must be so implausibly bloody. Even Tess herself is subject to this system that exchanges a human for an animal life, for it is Tess who wrings and breaks the necks of the wounded pheasants in the wood, Tess who is then compared to a bird, turning her eyes to Alec "with the hopeless defiance of the sparrow's gaze before its captor twists its neck" (351), and Tess who is eventually killed by the noose.

As many readers have observed, the whole fabric of Tess is woven of foreshadowings. Many of these involve the colour red and the words "blood", "bleeding", "bled". When Tess sees the words of the sign-painter, "Thy, Damnation, Slumbereth, Not", in red letters on the side of a barn, they go "well home to the reader's heart" (91). Alec declares to Tess that his feelings have "suddenly found a way open in the direction of you and [...] all at once gushed through" (349). Gradually the conviction grows upon the reader of Tess that a terrible crime is being prepared; the denouement will be bloody, it will very likely involve the piercing of the body, perhaps by a wound that goes "straight to the heart", that will "open" the body to gushing outflows; but the choice of weapon, who will wield it, where or when, who the victim will be, are unclear. The narrative is building up a vast stockpile of affect, but we do not know how it will be discharged.

Even when the murder has taken place, we still do not know exactly how it happened. It is true that we have Tess's own testimony, but that is all we have. Nobody saw her 
take up the knife, nobody saw her commit the crime. The workman who is sent into the room and discovers the body says "the gentleman in bed [...] has been hurt with a knife", a passive construction that places the victim on the receiving end of the "hurt" while leaving open the question of who actually caused it. "The point of the blade had touched the heart of the victim [...]. In a quarter of an hour the news that a gentleman [...] had been stabbed in his bed, spread through every street and villa of the popular watering-place" (405). The question is, how should agency be determined in such a case? Could the carving-knife somehow have exerted its own agency? With such questions we enter the territory of "vibrant matter" as charted by the political theorist Jane Bennett in her book of that title. Where our tendency is to think of matter as passive and inert, Bennett argues that material objects can be lively and spontaneous, in fact so full of life that they can be considered as agents. In Ruth Leys' summary, the theory of vibrant matter holds that "a lively, material, and effective agency is distributed throughout the world [...] that profoundly affects situations and events beyond the scope of human wishes and desires" (Leys 346-47).

This is not a new idea. In the summer of 1272, William le Cupere of Bedford climbed a ladder to get into the belfry of a church, fell and broke "the whole of his body", and the next day died. The jury at his inquest declared the ladder forfeit to the Crown, who would have the right to take it away and sell it or to claim an amount of money from its owner in lieu (Kirton-Darling 4). It would not be correct to say that the ladder was "found guilty", but clearly some notion of retributive justice centring on the ladder was involved. The legal term for an object forfeited in this way was "deodand" and enough trials involving objects seem to have taken place for various refinements to have emerged; for example, juries distinguished between objects at rest and objects in motion when determining the degree of culpability that an object such as a waggon might be said to have. "The trials of deodand never took place before ecclesiastical courts, but always before criminal courts. The jury consisted of twelve men, who investigated the occurrence and evaluated the instrument if it was proven to have caused the death. Its nature and value were then stated in the indictment by the jury" (Hyde 729). In one example quoted by Blackstone in his Commentaries on the English Laws, a penknife that was deemed to have caused a death was valued at six-pence, and this was the amount the King could demand. The instrument itself might be accursed (729). As one modern scholar has put it, "the deodand marked a world in which peril and possibility lay everywhere and in everything" and required people "to engage with the physical world's capacity for unruliness". Until it was abolished in 1846, deodand "acted as recognition of - not submission to- the inseparable place of the uncontrollable physical world in law" (Kirton-Darling 21).

The idea of "vibrant matter" is certainly present in Hardy. Indeed we might go further and say that, at times, Hardy's narratives could not progress at all without lively objects to impel them. Perhaps the most obvious example is the elm tree in The Woodlanders, whose threatening stance towards John South triggers the main events of the story. Or if not the tree, then the two sovereigns placed on Marty's mantle lookingglass that "confronted her [...] in such a manner as to suggest a pair of jaundiced eyes on the watch for an opportunity" (Hardy 1988, 53). Or the Valentine that Boldwood receives from Bathsheba and places on his mantle-piece, where it interacts with the objects in the room to attain a "deep solemnity" (Hardy 2002, 99), or the ear-rings that Elfride receives as a gift from Henry Knight, that face off against the banker's receipt she has received from her other suitor, Stephen: "There before her lay the deposit- 
receipt for the two hundred pounds, and beside it the elegant present of Knight [...]. She almost feared to let the two articles lie in juxtaposition: so antagonistic were the interests they represented that a miraculous repulsion of one by the other was almost to be expected" (Hardy 2009, 186). These objects participate in the world of intentionality and feelings; in Hardy we find ourselves truly in the midst of what Bruno Latour calls a "parliament of things" (Latour 142).

I have tried to suggest three ways in which weapons are deployed to help produce a sense of the uncanny in Hardy. First, weapons may appear out of nowhere. Writing of the scene of Prince's death in The Madder Stain, her psychoanalytic reading of Hardy, Annie Ramel points out that the tragedy happens on account of "an object which blocked the way", "a surplus object that jams the system", and suggests that "things go wrong in Hardy's tragic world because of an object that comes in excess of reality" (Ramel 15-16). What I find interesting about Hardy's use of weapons is that the shooting or puncturing object is indeed "added" to the scene, appearing suddenly out of nowhere, but then its "excessive" nature is immediately disclaimed: a shotgun is "usual" in farmhouses, the mail-cart is speeding along about its business "as it always did", the carving-knife belongs so obviously on a breakfast-table that you do not even notice it unless it is missing. Second, anything from a parasol to a set of bed-clothes can be a weapon; anything "homely", tame, familiar, can be rendered "unhomely", untamed, disruptive, in an instant. Finally, there is the possibility that weapons - like the many threatening, jaundiced, solemn, antagonistic objects in Hardy- have an agency of their own.

I would now like to take up the carving-knife in The Secret Agent, which is also of course implicated in the murder of a man who has used a woman selfishly. Adolf Verloc, pornographer and agent provocateur, has through a mixture of venal motives brought about the death of his simple-minded brother-in-law Stevie in a botched terrorist explosion. After the visit of the police, Verloc makes a long speech to his wife Winnie, Stevie's sister, in which he tries to shift the blame for Stevie's death onto her. He then lies down on the sofa and tries to assert his "marital authority" by calling Winnie to his side "in a peculiar tone [...] intimately known to Mrs Verloc as the note of wooing" (Conrad 202). Instead she gives full rein to her loathing for him and stabs him with a carving-knife:

She started forward at once [...]. Her right hand skimmed slightly the end of the table, and when she had passed on towards the sofa the carving knife had vanished without the slightest sound from the side of the dish. Mr Verloc heard the creaky plank in the floor, and was content. He waited [...]. He was lying on his back and staring upwards. He saw partly on the ceiling and partly on the wall the moving shadow of an arm with a clenched hand holding a carving knife. It flickered up and down $[. .$.

Mr Verloc, the Secret Agent, turning slightly on his side with the force of the blow, expired without stirring a limb [...]

She was giddy but calm. She had become a free woman [...]. Nothing moved in the parlour till Mrs Verloc raised her head slowly and looked at the clock with inquiring mistrust. She had become aware of a ticking sound in the room. It grew upon her ear, while she remembered clearly that the clock on the wall was silent [...]. Tic, tic, tic. (202-203)

Did Conrad have the stabbing of Alec in mind when he composed this scene? Hardy, of course, does not actually describe the murder. Was Conrad conscious of trying to surpass Hardy, to stage a scene Hardy had left out? There are numerous touchpoints: 
Winnie, like Tess, has bargained herself in exchange for the man's promise to take care of her family; her "footsteps" are heard "overhead" as she prepares to go out in hat and veil, like Tess; the murder weapon is the same; the "Tic, tic, tic" of Verloc's dripping blood recalls the "Drip, drip, drip" Mrs Brooks hears through the door in Tess. Fleeing the scene of the crime, Winnie bumps into Ossipon, who has always wanted to seduce her, and instantly enrols him in her plan of escape. Ossipon has always thought the Verloc marriage was sound, but Winnie sets him straight, saying: "YYou thought I loved him! [...] I was a young girl. I was done up. I was tired. I had two people depending on what I could do, and it did seem as if I couldn't do any more [...]. He seemed goodnatured, he was freehanded, he had money, he never said anything [...]. Do you know what he was? [...] He was a devil!"' (275-276). Next to Verloc, Alec d'Urberville seems almost a gem, but Winnie's description of her husband would serve as well for Tess's lover and tormentor, who also practised upon a young girl oppressed by family responsibilities. Ossipon does not understand at first what Winnie has done: "He wondered what was up with her, why she had worked herself into this state of wild excitement" (277). Angel, too, struggles to believe what Tess is telling him, "thinking from the strangeness of her manner that she was in some delirium" and has only imagined herself killing Alec (Hardy 2008b, 407). It is not a case of borrowing or indebtedness: Conrad did not need the example of Tess to create this scenario for The Secret Agent. But the example was there; it is almost inconceivable that Conrad did not know Hardy's novel, the occasion of so much attention and controversy just at the time (the early 1890s) that Conrad was beginning to imagine a literary career for himself, and it does not seem far-fetched to suggest that something of Tess and Alec d'Urberville made its way into Winnie and Adolf Verloc.

I want to suggest that something of the lodging-house carving-knife in Tess went into Winnie's carving knife in The Secret Agent. At the very least we may say that one of the resources Conrad had available to him when stockpiling affect in this object was Hardy's novel. Conrad, however, follows Chekhov's law more closely. In The Secret Agent the carving knife is introduced early on and toyed with several times in the novel. When Stevie is aroused to anger at a newspaper account of a military officer's brutality, "I had to take the carving knife from the boy," Mrs Verloc says: "He was shouting and stamping and sobbing. He can't stand the notion of any cruelty. He would have stuck that officer like a pig if he had seen him then [...]. Some people don't deserve much mercy" (Conrad, 60). Later, laying out the table for her husband's meal, Winnie examines "the sharp edge of the carving knife" (193) before placing it on the dish and calling Verloc's attention to the beef. Verloc tries to win his wife's sympathy for the terrible risks he has run as a secret agent: "What was the good of telling you that I stood the risk of having a knife stuck into me any time these seven years we've been married? I am not a chap to worry a woman that's fond of me" (238). On balance, however, Verloc is optimistic: "He really believed that it would be upon the whole easy for him to escape the knife of infuriated revolutionists" (249). When Verloc finally decides to eat: "He partook ravenously, without restraint and decency, cutting thick slices with the sharp carving knife, and swallowing them without bread" (253). Mrs Verloc decides to run away from him, but fears he will simply overpower her: "She could scratch, kick, and bite - and stab too; but for stabbing she wanted a knife" (256). Thus the scene is set for murder. Unlike Hardy, Conrad gives us plenty of intimations that the carving-knife is going to feature in this "domestic drama". As Chekhov might 
have said, if there is a carving-knife on the table in the first act, by the third act it must be used.

However, what I want to point to is the way that the suggestion of the carving-knife's agency is woven into the handling of the scene. It would be more precise to say that agency is distributed between human and object. Just as Mrs Brooks registers the absence of the carving-knife, though we never see anyone take it, so the narrator of The Secret Agent notes only that the carving-knife has vanished from the table, not that Winnie has scooped it up. Mr Verloc does not see who stabs him, only "the moving shadow of an arm [...] holding a carving knife". On the surface, Conrad's approach to imbuing the domestic carving knife with menace is more direct than Hardy's; but both writers seem to blur the boundaries between human and object and hint at the way agency is shared. For all that Conrad's novel is set in a completely different milieu to Hardy's, they are both, as the Assistant Commissioner observes of the Greenwich bomb affair, essentially "domestic drama"; but the drama is acted as much by the objects as by the humans who make up its cast.

\section{BIBLIOGRAPHY}

Bennett, Jane, Vibrant Matter: A Political Ecology of Things, Durham, NC: Duke UP, 2009.

Conrad, Joseph, The Secret Agent (1907), ed. Roger Tennant, Oxford: OUP, 1991.

Hardy, Thomas, The Complete Poems, ed. James Gibson, London: Macmillan, 1976.

Hardy, Thomas, Far from the Madding Crowd (1874), ed. Suzanne B. Falck-Yi, Oxford: OUP, 2002.

Hardy, Thomas, A Pair of Blue Eyes (1873), ed. Alan Manford, Oxford: Oxford UP, 2009.

Hardy, Thomas, The Trumpet-Major (1880), ed. Richard Nemesvari, Oxford: OUP, 1991.

Hardy, Thomas, A Laodicean (1881), ed. John Schad, London: Penguin, 1997.

Hardy, Thomas, The Mayor of Casterbridge (1886), ed. Dale Kramer, Oxford: OUP, 2008.

Hardy, Thomas, The Woodlanders (1887), ed. James Gibson, London: Penguin, 1988.

Hardy, Thomas, Tess of the d'Urbervilles (1891), eds. Juliet Grindle and Simon Gatrell, Oxford: OUP, 2008.

Hardy, Thomas, Jude the Obscure (1895), ed. Patricia Ingham, Oxford: OUP, 2008.

Hyde, Walter Woodburn, "The Prosecution and Punishment of Animals and Lifeless Things in the Middle Ages and Modern Times", University of Pennsylvania Law Review and American Law Register 64.7 (May 1916): 696-730.

Kirton-Darling, Edward, "Searching for Pigeons in the Belfry: The Inquest, the Abolition of the Deodand and the Rise of the Family", Law, Culture, and the Humanities 14.3 (Dec. 9, 2014): 439-461.

Latour, Bruno, We Have Never Been Modern, Cambridge, MA: Harvard UP, 1993.

Leys, Ruth, The Ascent of Affect: Genealogy and Critique, Chicago: U of Chicago P, 2017. 
Ramel, Annie, The Madder Stain: A Psychoanalytic Reading of Thomas Hardy, Leiden: Brill, 2015.

Ray, Martin, Thomas Hardy Remembered, Abingdon: Routledge, 2016.

Stendhal, The Charterhouse of Parma (1839), London: Penguin, 1976.

\section{NOTES}

1. I am grateful to Dr Annie Ramel for pointing out the connection between "unhomely" and "uncanny".

2. I am grateful to Yui Kajita (University of Cambridge) for suggesting these examples.

\section{ABSTRACTS}

This paper explores a particular sub-category of objects, namely weapons. In Hardy's work, guns, swords, cannons, and other tools of destruction are put to use with disturbing frequency not in the public arena of battle but in private spaces, for courtship (as in Troy's sword), or to settle what the police might call domestic incidents (as in Boldwood's gun). The insinuation into private/domestic space by weapons designed for impersonal combat is met by a movement in the opposite direction which sees the conversion of everyday objects into weapons. The suddenness with which weapons appear in the narrative, the fact that any object may be repurposed as a weapon, and the suggestion that weapons, like other objects in Hardy, have agency, contribute to the production of the uncanny. I conclude by suggesting grounds for comparison between Conrad's The Secret Agent and Tess of the d'Urbervilles. In both novels, a woman is practised upon by an unscrupulous man and eventually revenges herself in the same way, using the same object, a carving-knife, as weapon. Although the two novelists use different techniques to stockpile affect in the object for sudden, cataclysmic disbursement, they both leave open the question of the object's agency.

Cet article étudie une catégorie bien particulière d'objets, à savoir les armes. Dans l'œuvre de Hardy, les fusils, épées, canons et autres armes de destruction sont utilisés avec une régularité inquiétante, non pas dans la sphère publique mais dans des espaces privés, qu'il s'agisse de séduire une femme (ce que fait l'épée de Troy) ou de régler ce que la police pourrait nommer des « incidents domestiques » (ce que fait le fusil de Boldwood). Et en retour de ce mouvement, par lequel des armes conçues pour les combats collectifs s'insinuent dans l'espace privé et/ou domestique, un mouvement inverse voit des objets du quotidien se convertir en armes. La soudaineté avec laquelle les armes apparaissent dans le récit, le fait que tout objet puisse être reconfiguré comme arme, et la suggestion que les armes sont douées d'agentivité, comme bien des objets chez Hardy, contribuent à produire un sentiment d'inquiétante étrangeté. L'article s'achève en proposant des éléments de comparaison à ce sujet entre Tess of the d'Urbervilles et le roman de Conrad The Secret Agent. Dans les deux romans, une femme est manipulée par un homme sans scrupule, et finit par se venger en utilisant en guise d'arme le même objet, un couteau de cuisine. Même si les deux romanciers utilisent des techniques différentes pour charger d'affect les objets, en vue d'un dénouement brutal et destructeur, ils posent tout deux la question ambiguë d'une possible agentivité des objets. 
INDEX

oeuvrecitee Tess of the d'Urbervilles, Secret Agent (The)

Mots-clés: objet, arme, couteau, fusil, épée, inquiétante étrangeté, deodand, matière vibrante, Conrad (Joseph)

Keywords: object, weapon, sword, gun, knife, uncanny, deodand, vibrant matter, Conrad (Joseph)

\section{AUTHOR}

\section{ANDREW HEWITT}

Andrew Hewitt is a part-time PhD student at the University of Hull, where his supervisor is Professor Jane Thomas. His focus is the role of emotion and affect in Hardy's fiction. He has presented at a number of conferences and study days and his papers have appeared in the Thomas Hardy Society Journal. He works for the examination board of the University of Cambridge 